\title{
Market Structure, Income Diversity, and Stability: Empirical Study of Banking Industry Indonesia
}

\author{
Hadi Satria Ganefi ${ }^{*}$, Wita Juwita Ermawati², Dedi Budiman Hakim ${ }^{3}$ \\ 1Pancasakti University Tegal, Indonesia \\ ${ }^{2}$ Departement of Management IPB University, Indonesia \\ ${ }^{3}$ Departement of Economic IPB University, Indonesia \\ *Corresponding Author: hadisatria.g@upstegal.ac.id
}

\begin{abstract}
Banking as an intermediary institution has an essential role in the world of economy. Apart from providing financing to the real sector, banks currently still dominate the Indonesian financial system with an asset share of $77.25 \%$. Based on the existing conditions, Indonesia's banking market is still dominated by several banks, especially in the BUKU 4 bank group. This is to indicate a bank of Indonesia is generally still facing relatively low competition. In addition, the large concentration makes it necessary for banks to divert their main activities by diversifying into non-traditional activities in carrying out their operations. This study aims to analyze how the market competition in Indonesia during the period 2014-2019 and examine the effect of competition and diversification income on stable banks. The panzer rosse model is used to analyze the market structure; for diversification, this research uses calculations with the Herfindahl Hirshman Index while stability uses two risk measures, namely NPL and Z Score, as a proxy for stability. The results show that, in general, the banking industry is under monopolistic competition. Competition has a significant effect on stability banks as measured through NPL risk, and this research supports the competition-fragility paradigm. A meanwhile, diversification income variables have not to effect on stability.
\end{abstract}

Keywords: Competition; Panzar Rosse; Diversification; Stability; Risk-Taking

\section{INTRODUCTION}

Indonesia is one of the countries categorized as a bank-based country, where an economy is still largely dependent on the existence of banks. This can be seen from the large dominance of the banking market asset on the financial system of 77.25\% (Bank Indonesia, 2019). Data from the Financial Services Authority noted that the sum of banks in Indonesia from 2014-2019 tended to decline from 119 to 110. The decrease was caused by corporate actions such as consolidation (mergers/acquisitions) and revocation of operating licenses. The corporate action taken is to strengthen not only capital but also to improve the market 
network so that it is expected to be able to compete competitively. However, based on OJK data, the banking market is currently still dominated by several banks, especially in the BUKU 4 bank group. This can be seen from 2014-2019 that the group of banks also tend to there increase in market share both in terms of credit, deposits, and assets with an average share of $50.82 \%$ in loans, $47.94 \%$ in deposits, and $48.42 \%$ in assets as shown in Figure 1.

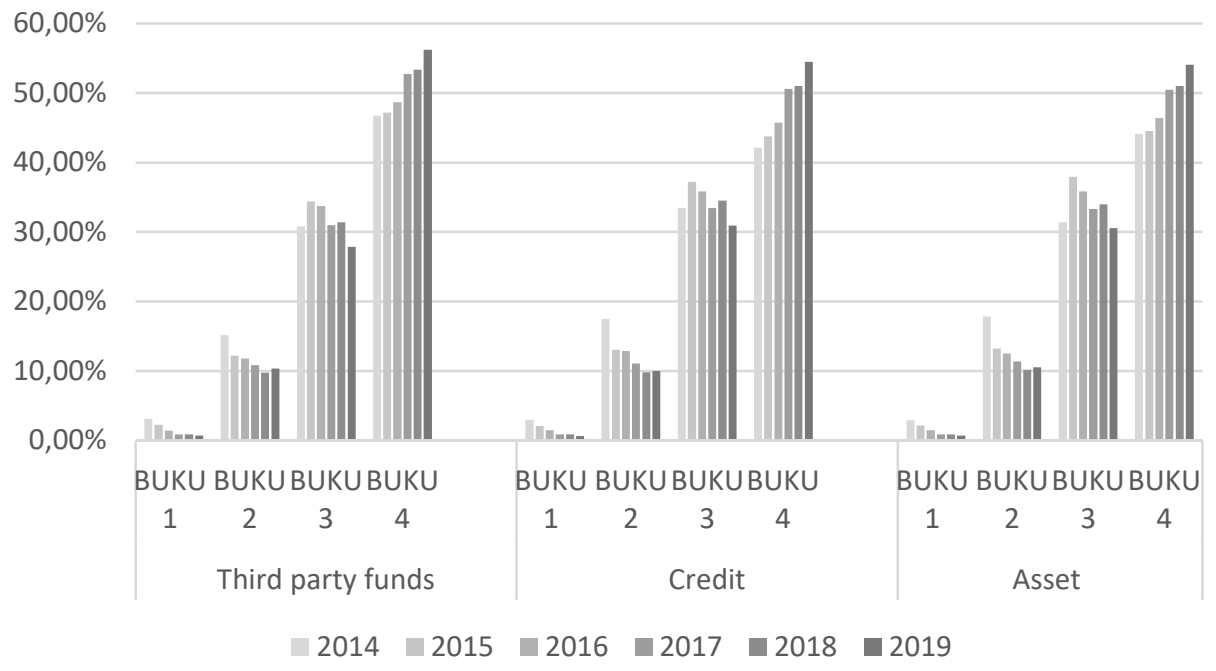

Figure 1. Market Share Commercial Banking of Indonesian 2014-2019 Source: Financial Services Authority, 2020

The high-level concentration has the potential to create an oligopoly or monopoly competition. In general, the measurement of the level of competition can be measured by two approaches, structural and non-structural. Research related to competition, especially banking in Indonesia, still uses structural methods by looking at market structure information, namely the market share of several large banks against the number of existing industries known as market concentration. In comparison, the non-structural method focuses more on the company's financial information and assesses the difference in cost structure from competitive prices. Some methods as usually to measure competition with the non-structural approach are the Iwata model (1974), the Bresnahan-Law model (1982), and the Panzar-Rosse model (1987).

Changes in the level of competition can have an impact on risk banks, so this can too have an impact on banking stability (Berger et al., 2013). There are two contradictory views on explaining the relation between competition and banking stability. The first paradigm of competition fragility (concentration-stability) explains that competition can reduce profits banks and encourage behavior banks to take greater risks to increase profits (Noman et al., 2017). Banks with a large market share will tend to have a stronger bargaining position so that they are more likely to make higher profits. When the Bank manages to get high profits, the Bank tends to be more careful to reduce risk (Wibowo, 2017).

The second view is competition stability (concentration fragility); namely, a competitive market will set interest rates at a low level to attract customers. Banks tend to avoid the risk of loss. On the other hand, low competition marked by a higher level of concentration in the banking market will lead to lower financial fragility and pricing power, increasing banking risk exposure (Molyneux et al., 2014). Another rationale is that a concentrated banking market will increase moral hazard in taking higher risks. This condition can 
generate a risk of loss, which in turn can affect the Bank's stability. This is because they believe in the too big to fail policy that they will explicitly or implicitly be protected by the government safety net (Apriadi et al., 2017). The banking system concentrated in a few large banks can threaten the risk of failure and cause losses involving many depositors. Thus the government will always provide safety guarantees in order to avoid the possibility of systemic risks (Clark et al., 2017). The existence of high market pressure pressures causes each Bank to need to increase its income diversification in order to survive in carrying out its operations (Revida 2019).

The difference in market share, which is quite significant, is a challenge for most banks to continue to exist in their business activities. One of the efforts that can be done is to improve the quality of financial services that switch to non-traditional businesses. Currently, it is known that most banks have expanded their income sources from previously focused on traditional financing by relying on spread rates, but now every Bank is required to be more innovative in creating income outside of its traditional business such as treasury trading, bancassurance, card business, transactional business through optimization of digital banking and other payment transaction services that generate noninterest income. The diversification aims to fulfill the demand function as well as maintain cash flow and increase profits so that it can provide financial benefits. Some previous literature emphasizes the importance of income diversification as an effort to reduce risk (Abuzayed 2018).

This study analyzes the level of competition in banking in Indonesia and the effect of competition and income diversification on stability. Apart from giving empirical information, this research is expected to contribute practically to banking on implementing market control strategies. For regulators, this research is expected to be the basis for policy formulation in maintaining banking stability, given the importance of this institution in supporting the country's economy.

This paper's process is as follows - section 1 Introduction, which is the background. Section 2 describes the development of the Hypothesis. Section 3 describes the methods, data, and analysis. Then section 4 provides the results, discussion, and conclusions.

\section{HYPOTHESIS DEVELOPMENT}

\section{Market Structure}

Market concentration, also known as monopoly power, is the company's ability to set prices above its marginal cost in an imperfectly competitive market environment. In imperfect competition, it can be seen from the entry barriers that are strong enough for companies outside the market to enter the market. One of them is the oligopolist as the price leader, namely the seller who has the largest market share. In Indonesian banking, generally, the banking market is mainly focused on BUKU 4 or banks with the largest capital ownership of seven banks from 110 banks with control of half of the entire existing market. It can be assumed that the Indonesian banking industry is in imperfect competition conditions. 
H1: Commercial banks in Indonesia are in a condition of imperfect competition

\section{The Effect Competition on Stability}

The competition-stability view states that a highly concentrated market causes financial fragility and bank behavior to take greater risks. In terms of "too big to fail" or "to important to fail" which Bank is concentrated to large banks, it has the potential to threaten the health and safety of the banking system as a whole so that it poses a systemic risk to the financial system and economy. The theory of stability-competition is built on the paradigm of risk-shifting theory, which states that banks with large market power have a significant impact on systematic risk. This causes the government will more attention, resulting in bank moral hazard behavior by setting high-interest rates (Clark et al. 2018). This will encourage borrowers to use the funds on riskier projects leading to high default. In contrast to the competition, fragility has the opposite paradigm. In this view, a concentrated market will greatly benefit, considering that banks with large market power have a bargaining position that can impact the number of profits obtained. When a bank manages to get high profits, banks tend to be more careful in running their business and reduce the high risk of taking high that can have an impact on bank stability. Based on this statement, the Hypothesis developed is

H2: Competition affects bank stability

\section{The Effect of Income Diversification on Stability}

Currently, bank activities are not only focused on the intermediation function, where credit is the main source of income. Currently, it is known that banks have expanded their sources of income through various services in the field of financial services. According to Shim (2019), diversification can provide benefits related to scope or economies of scale, can reduce income volatility and other synergies on Finance. In addition, according to Alkhouri and Arouri (2018), diversification in the banking industry may create value. The increase in the value of banks comes from the economic scope; banks usually benefit from long-term relationships with their customers that can help them collect important and diverse information on other customers, which can be used in shaping their investment portfolio. In addition, the benefits of technological progress can be attributed to diversification. This is because the larger the Bank, diversifying its products by utilizing technology can improve performance and profit. In their research, Lee et al. (2014) show that income diversification has a positive effect on banking performance and stability. In comparison, Nguyen et al. (2012), in their research, income diversification can positively benefit bank stability, especially banks with large market power. Based on this statement, the Hypothesis developed is H3a.

\section{H3a: Diversification has a positive effect on bank stability}

Following Amidu and Wolfe (2013), Abuzayed et al. (2018), and Ul Huq (2019), This study also specifically analyzes the diversification of the Bank's income structure obtained from non-interest (fee-based income) is namely commissions or fee, trading income, and other non-interest income. The higher the income from non-interest products produced will increase the profits of a bank and be able to reduce the risk of loss. In their research, Messier et al. (2014) show that income generated from non-interest provides benefits to the profits banks. Meanwhile, according to Sawada (2013), non-interest income, especially those from fees and commissions, can reduce non-systematic risk. Furthermore, with the increasing number of trade transactions, both nationally and internationally, transaction services in 
foreign currency and securities have increased. This can have a positive impact on profit banks. Based on this statement, the Hypothesis developed is $\mathrm{H} 3 \mathrm{~b}, \mathrm{H} 3 \mathrm{c}$, and $\mathrm{H} 3 \mathrm{~d}$.

H3b: Commission income has a positive effect on stability

H3c: Trading income has a positive effect on stability

H3d: Other non-interest income has a positive effect on stability

Based on the development and explanation of the Hypothesis, the research framework can be described as following Figure 2 .

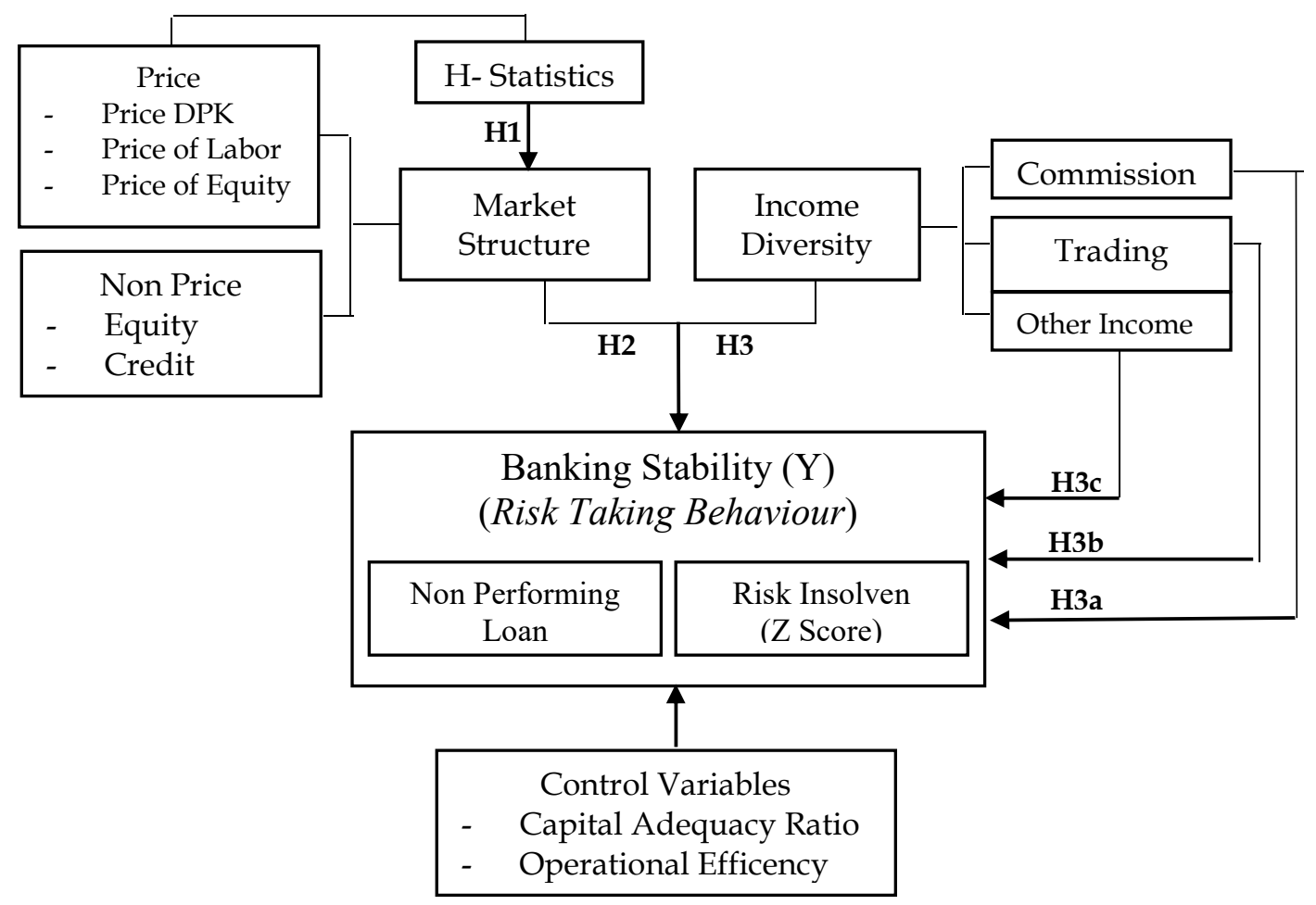

Figure 2. Research Framework

\section{METHOD, DATA, AND ANALYSIS}

The type of data used in this study is panel data in the form of the number of commercial banks operating in Indonesia during 2014-2019 Using. Secondary data was obtained through the annual financial statements of each Bank, Indonesian banking statistics reports, journals, and previous research. The objects studied were all commercial banks which were divided based on the category of book one until to four. The sampling technique used the purposive sampling method with the criteria as shown in Table 1. 
Table 1. Number of Samples

\begin{tabular}{lr}
\hline Criteria & Amount \\
\hline A commercial bank in Indonesia during operational 2014-2019 & 110 \\
Conventional of commercial Bank & 88 \\
Incompleted financial reports \& ratio & 24 \\
Number of final samples bank & 64 \\
BUKU 1 (Core capital < 1 trillion) & 15 \\
BUKU 2 (Core capital 1-5 trillion) & 25 \\
BUKU 3 (Core capital 5-30 trillion) & 17 \\
BUKU 4 (Core capital > 30 trillion) & 7 \\
Period of observation (Annual) & 6 \\
Number of observation & 384 \\
\hline
\end{tabular}

\section{Measuring Competition}

The panzar rosse model is used to measure competition. This model defined the level of competition indicator with H-Statistic, which is the amount of elasticity of bank income to the input price factor. It is assumed that there are n-inputs used and the output produced by the Bank is one, namely credit; according to Bikker et al. 2006 model equation of this PR is as following equations 1 and 2.

$$
\begin{aligned}
\log _{\mathrm{i}} & =\sum_{i=1}^{n} \beta i \log \mathrm{w}_{\mathrm{i}}+\sum_{j=1} \mathrm{Yi} \log C F_{j}+\text { error } \\
H & =\sum_{i=1}^{n} \beta_{i}
\end{aligned}
$$

LogR : Revenue bank i

Wi $\quad$ : Input Price bank i

CF : Input non price

$\mathrm{H} \quad$ : Level competition (H-statistics)

The value of H-statistics as a measure of competition is obtained from the sum of all the elasticity of the input factor prices $\left(W_{\mathrm{i}}\right)$ to revenue bank $(\log R)$ in the regression equation. The $\mathrm{H}$-statistic value is between 0 and 1 ; the $\mathrm{H}$-stat value below 0 indicates that the level of competition in an industry is collusive competition (joint monopoly). The H-statistical value of less than 1 indicates the level of competition in an industry is monopolistic competition and the H-statistical value equal to 1 indicates the level of competition is perfect competition.

The PR model provides the main assumption that the $\mathrm{H}$-statistical test should be carried out in observing long-term equilibrium. In the long-run equilibrium, the rate of return must not correlate with the input price variable (Hapsari 2019). Therefore, the value of ROA is used as the dependent variable. This is because ROA is a variable that describes the profitability of the company. The extent to which the Bank can maximize profitability without being influenced by the cost increase factor is the equation for testing longrun equilibrium conditions following equations 3 and 4 .

$$
\begin{aligned}
\ln (1+\mathrm{ROA}) & =\sum_{i=1}^{n} \beta i \log \mathrm{w}_{\mathrm{i}}+\sum_{j} \mathrm{Yi} \log C F_{j}+\text { error } \\
E & =\sum_{k-1}^{K} \beta_{k}=0
\end{aligned}
$$




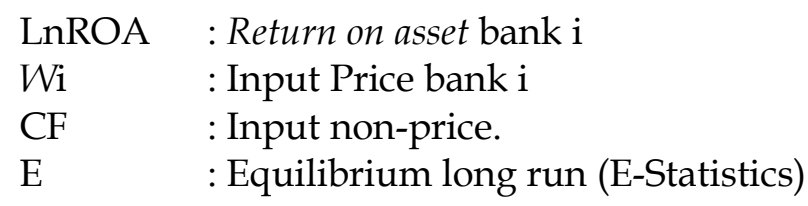

Equilibrium test with Wald analysis with the interpretation that if $\mathrm{E} \neq 0$ the banking industry is not in equilibrium long run hile if the value of E-Statistics $=0$ indicates the market is in a equilibrium long run, in other words, individuals in industry have to operate under optimal and stable conditions. Thus, the competition specification model as done by Nguyen (2017), Mustafa and Toçi (2017) on the panzer rosse model as following equations 5 and 6. Moreover, the Variable Description can be seen in Table 2.

Long run equilibrium test model

$$
\begin{aligned}
\ln \left(\text { ROA }_{i t}\right)= & \beta_{0}+\beta_{1} \ln \left(\text { PThirdPartyFunds }_{i t}\right)+\beta_{2} \ln \left(\text { PLabor }_{\text {it }}\right)+\beta_{3} \ln \left(\text { PEquity }_{i t}\right)+ \\
& Y_{1} \ln \left(\text { EQTA }_{\text {it }}\right)+Y_{2} \ln \left(\text { Credit }_{i t}\right)+D_{1}+D_{2}+D_{3}+D_{4}
\end{aligned}
$$

Competition analysis model

$$
\begin{aligned}
\ln \left(\text { TREV }_{\text {it }}\right)= & \beta_{0}+\beta_{1} \ln \left(\text { PThirdPartyFunds }_{i t}\right)+\beta_{2} \ln \left(\text { PLabor }_{i t}\right)+\beta_{3} \ln \left(\text { PEquity }_{i t}\right)+ \\
& Y_{1} \ln \left(\text { EQTA }_{i t}\right)+Y_{2} \ln \left(\text { Credit }_{i t}\right)+D_{1}+D_{2}+D_{3}+D_{4}
\end{aligned}
$$

Table 2. Variable Description

\begin{tabular}{ll}
\hline Variable & Description \\
\hline lnROA & Rasio return on asset bank \\
PThirdPartyFunds & Interest Income to total aset \\
PLabor & (Cost Labor to total asset) \\
PEquity & Capital price input proxy (total biaya operasional di luar biaya tenaga \\
& kerja to asset) \\
EQTA & (equity to asset) \\
Credit & Credit to Aset \\
$\mathrm{D}_{1}$ & Dummy Variable (BUKU 4) \\
$\mathrm{D}_{2}$ & Dummy Variable (BUKU 3) \\
$\mathrm{D}_{3}$ & Dummy Variable (BUKU 2) \\
$\mathrm{D}_{4}$ & Dummy Variable (BUKU 1) \\
\hline
\end{tabular}

The value of the long run equilibrium test is obtained from the sum of the coefficients $\left(E=\beta_{1}+\beta_{2}+\beta_{3}\right) n$ the ROA equation, hile the coefficient value $Y_{1}+Y_{2}+Y_{3}$ is a control variable from input factors non-price. The value of level competition (H-statistics) is obtained from the sum of the coefficients $\left(H=\beta_{1}+\beta_{2}+\beta_{3}\right)$ on the equation InTREV, while the coefficient $Y_{1}+Y_{2}+Y_{3}$ is control variables for non-price input factors. 
Table 3. Interpretation Result H Statistics

\begin{tabular}{cl}
\hline H- Statistics & Market Structure \\
\hline $\mathrm{H} \leq 0$ & Competitive Behaviour is in Line Eith Monopoly \\
$0<\mathrm{H}<1$ & Monopolistic Competition \\
$\mathrm{H} \geq 1$ & Perfect Competition \\
E - Statistics & Market Condition \\
$\mathrm{E}=0$ & Longrun Equilibrium \\
$\mathrm{E} \neq 0$ & The Market is in Dynamic Conditions \\
\hline
\end{tabular}

Source: (Bikker and Haaf 2002)

The PR model examines the effect of changes in price input factors on the income earned banks. In other words, the PR model describes the elasticity of bank income to input prices. Basically, all banks will experience an increase in those banks. Its marginal cost is due to an increase in factor input prices. However, the reaction of each Bank to these changes will be different depending on the type of market the Bank has, according to Ventouri (2018).

Furthermore, if the market conditions are in monopolistic competition, the increase in costs will increase income at a lower rate than the increase in costs. In a perfectly competitive market, an increase in input prices which can increase marginal costs, will force some firms out of the market so that the remaining firms will get an increase in demand which then leads to an increase in selling prices and hence the amount of revenue will be equal to the amount of the increase in costs.

Banks are in a situation of zero profit, free entry, and free exit in a perfectly competitive market. Meanwhile, in a monopoly or oligopoly market, an increase in the price of inputs will increase the marginal cost, which leads to a decrease in output and consequently can reduce the level of income.

\section{Income Diversity}

In measuring diversification, following the research Lee et al. (2014), Abuyazed et al. (2018), and Trinugroho et al. (2018) using the Herfindahl Hirshman Index measurement technique by exploring various types of income consisting of interest and non-interest. The two types of income make it possible to identify whether diversification activities can give to benefit by financial. The diversification measure equation is as following equation 7 .

$$
H H I_{D I V}=1-\left[\left(\frac{\mathrm{NII}}{\mathrm{NII}+\mathrm{NON}}\right)^{2}+\left(\frac{\mathrm{NON}}{\mathrm{NII}+\mathrm{NON}}\right)^{2}\right]
$$

Where NII is net interest income, non is non-interest income. Following Fereira et al. (2019), the index value covers the range from 0.5 to 1 . The value of the diversification index is equal to 0.5, then the Bank's income is obtained in a balanced manner between interest and non-interest (maximum diversification). On the other hand, the diversification value is greater than or equal to 1 , indicating that the level of diversification is only focused on one source (minimum diversification). In non-interest income, there are also three types of income, namely commission income, trading income, and other non-interest income. Similarly, the research of Bustaman et al. (2017) and Brunnermeier et al. (2020) calculates 
the value of commission, trading, and other non-interest income, which is calculated based on the respective value to total assets.

\section{Stability}

For measuring stability, we use the NPL and Z-score as suggested and commonly used in banking literature (Lepetit et al. 2008; Laevenand Levine. 2009; Cihak and Hesse, 2007,2010; Wibowo. 2016; Ibrahim et al. 2018; Louhichi et al. 2018). The NPL ratio is calculated as the ratio of bad loans to total loans. This analysis makes it possible to understand whether competition has an impact on bank behavior in taking risks through credit, as measured by the level of non-performing loans. In addition to NPL, insolvency risk is calculated as a proxy for a measure of bank stability. Insolvency risk is calculated by the Z-score, which is a measure of health by combining the capital and profit of a bank for the risks faced. The $\mathrm{Z}$ score can also be considered as a measure of a bank's distance to default because it calculates the standard deviation of earnings that continues to fall, pushing banks into bankruptcy (Shim 2019). As also used by Nguyen et al. (2012), Amidu and Wolfe (2013) Z score is calculated using the following equation 8.

$$
\mathrm{Z} \mathrm{ROA}_{i t}=\frac{\left(R O A_{i t}+\mathrm{CAR}\right) i t}{\sigma \mathrm{ROA}}
$$

Where $\mathrm{ROA}_{i t}$ is the return on assets for bank $\mathrm{i}$ at time t. CAR $\mathrm{R}_{\mathrm{it}}$ is the amount of equity to assets ratio of Bank $i$ at time $t$. $\mathrm{ROA}_{\text {it }}$ is computed as the standard deviation of return on assets within each individual bank time $t$. After obtaining the measures of competition, income diversification, and stability, we run the regression specification model of competition, income diversification, and stability as following equation 9.

$$
\begin{aligned}
\left(\text { Stability }_{i t}\right)= & \beta_{0}+\beta_{1} \text { Competition }_{i t}+\beta_{2} \text { DIV }_{\text {it }}+\beta_{3} \text { Comm }_{i t}+\beta_{4} \text { Trad }_{i t}+\beta_{5} \text { Oth }+ \\
& B_{6} \text { CAR }_{\text {it }}+\beta_{7} \text { BOPO }_{\text {it }}+e_{i t}
\end{aligned}
$$

Stability is a measure of risk measured by two proxies, i.e., credit risk (NPL) and insolvency risk, competition is a measure of the Bank's market structure, div is the level of diversification of bank income between interest and non-interest, comm is commission, trad is non-interest trading income, and other non-interest. The control variables at the bank level used include the capital ratio and the level of efficiency.

\section{RESULTS}

\section{Competition in Banking Industry Indonesia}

The use of the panzar rosse model in measuring industrial competition requires the assumption of a necessary condition, where the observation sample as a whole must be in a state of long run equilibrium. The Wald test carries out this test by adding up the value of the E-statistical coefficient of the price input variable to LN (ROA), which is the dependent variable as shown in table 4.

Table 4. Equilibrium test

\begin{tabular}{ccc}
\hline E-statistics & Prob F-stat (wald test) & Market Condition \\
\hline 0.0041 & 0.2876 & $\begin{array}{c}\text { The industry is in long-run } \\
\text { equilibrium }\end{array}$ \\
\hline
\end{tabular}

Source: Data Processed, 2020 
The results of the Wald test show that the industrial market is in a long-run equilibrium condition. This can be seen from the probability value of 0.2876 . it can be interpreted that any increase in the price of production inputs will have a minimum or even no effect on the profitability (Ventouri 2018).

In the competitive structure of the Indonesian banking market, we use a panel data regression analysis model with the Feasible Generalized Least Square (FGLS) model. The FGLS model's choice is because in the selection of the fixed effects model, there is a violation of the autocorrelation assumption, so it needs to be overcome by generalizing with the Generalized Least Square (GLS) model. In addition, the consideration of dummy variables in the regression allows for full multicollinearity or near singular matrix in the fixed effects model, which results in the estimation not being able to be carried out. The results of the estimation of the competitive structure of the banking market are shown in table 5 .

Table 5. Regression Test Market Structure

\begin{tabular}{cllll}
\hline Independent & \multicolumn{4}{c}{ Dependent Variable (Total Revenue) } \\
\cline { 2 - 5 } Variable & OLS & FEM & GLS & FGLS \\
\hline InP_DPK & $0.1402^{* * *}$ & $0.1444^{* * *}$ & $0.1352^{* * *}$ & $0.1305^{* * *}$ \\
& $(0.0000)$ & $(0.0000)$ & $(0.0000)$ & $(0.0000)$ \\
lnP_Labor & -0.0049 & -0.0222 & -0.0154 & -0.0164 \\
& $(0.7418)$ & $(0.1297)$ & $(0.2599)$ & $(0.2352)$ \\
InP_Equity & $0.3531^{* * *}$ & $0.1750^{* * *}$ & $0.2566^{* * *}$ & $0.2531^{* * *}$ \\
& $(0.0000)$ & $(0.0000)$ & $(0.0000)$ & $(0.0000)$ \\
lnEQTA & -0.0137 & -0.0193 & -0.0122 & -0.0103 \\
& $(0.6324)$ & $(0.6395)$ & $(0.7128)$ & $(0.7648)$ \\
lnCredit & $0.3344^{* * *}$ & $0.3962^{* * *}$ & $0.3740^{* * *}$ & $0.3771^{* *}$ \\
& $(0.0000)$ & $(0.0000)$ & $(0.0000)$ & $(0.0000)$ \\
Cons & -0.6492 & -1.2466 & -0.9879 & -1.1188 \\
& $(0.0000)$ & $(0.0000)$ & $(0,0000)$ & $(0.0000)$ \\
H-statistics & & & & $\mathbf{0 . 3 8 3 6}$
\end{tabular}

\section{Group Bank}

D1_BUKU 4

0.0295

(0.8604)

$\begin{array}{ll}\mathrm{D}_{2} \_ \text {BUKU } 3 & 0.1206\end{array}$

(0.4568)

$\begin{array}{ll}\text { D__BUKU } 2 & 0.1069\end{array}$

(0.5038)

$\begin{array}{ll}\mathrm{D}_{4} \_ \text {BUKU } 1 & 0.1367\end{array}$

$(0.3987)$ 
Based on the estimation results, the value (H-statistics) was obtained at 0.3836 . This value is obtained from the number of coefficients on the price input variable, which is significant. Table 3 it is generally known that Indonesian banks operate under monopolistic competition.

The price factor variable, namely the price of TPF and capital, is the most significant value in influencing income. This shows that an increase in the cost of third-party funds and capital price can increase bank income by $0.1305 \%$ (TPF) and $0.2531 \%$ (capital price). Meanwhile, viewed from non-price factors partially, the variable that significantly influences income is the number of credits. This is in accordance with the main source income function of banks as intermediary institutions

In the dummy variable, all groups of banks have no significant value, which means that our research did not find indications of bank behavior that leads to imperfect competition (Oligopoly), especially in the large bank group (BUKU 4). This gives the assumption that each bank group has a different business segment.

Income diversification, which is a non-traditional activity, is carried out to compensate for the decline in the income generated from traditional activities. Table 6 shows that banks in Indonesia, on average, diversify their income, which is still relatively small or equal to $27.1 \%$ of the total income. The non-interest income earned is mostly generated from commission income followed by trading and other non-interest.

Table 6. Income Diversification and Stability

\begin{tabular}{ccccccc}
\hline \multirow{2}{*}{ Years } & \multirow{2}{*}{ Div } & Comm & Trading & Other & \multicolumn{2}{c}{ Stability (Risk) } \\
\cline { 6 - 7 } & & & & & NPL & Z-Score \\
\hline 2014 & 0.254 & 0.090 & 0.057 & 0.037 & 2.59 & 58.23 \\
2015 & 0.254 & 0.081 & 0.064 & 0.039 & 2.84 & 63.16 \\
2016 & 0.259 & 0.077 & 0.065 & 0.042 & 3.30 & 68.87 \\
2018 & 0.276 & 0.083 & 0.067 & 0.046 & 3.25 & 69.91 \\
2019 & 0.281 & 0.084 & 0.071 & 0.056 & 3.16 & 67.35 \\
Average & 0.299 & 0.087 & 0.083 & 0.068 & 3.22 & 54.05 \\
\hline
\end{tabular}

Source: Data Processed, 2020

In addition, in terms of stability, as measured by two proxies for NPL risk and insolvency (Z Score), the average NPL risk of commercial banks tends to increase, especially in 2014-2017 and then declining in 2018. During the years 2014-2019, despite the trend of increase, the overall value of NPL is still below the maximum limit of $5 \%$. Meanwhile, the average value of Z Score from 2014-2019 commercial banks is 63.59, which indicates the level of stability in terms of insolvency risk more to increase. In 2018 and 2019, value risk insolvency tends to increase, and this is due to the large volatility of ROA as a result of the losses obtained from operational activity.

The results of our estimation of the NPL variable use the Generalized Least Square (GLS) regression model for estimator. Partially, the H-statistical variable as a measure of competition has a significant negative effect on the level of NPL with a coefficient value of -0.5340 . This shows that competition can reduce the occurrence of bank risk-taking in terms of offering credit. CAR variable has a significant positive effect on NPL. The higher capital, the greater banks to the ability to minimize credit risk that occurs so that non-performing loans that occur in the Bank will be lower with the number of reserve funds obtained from 
the ratio of capital and weighted assets. Meanwhile, the BOPO variable is a measure of efficiency, has a positive effect on NPL. One of the components of banking BOPO is the interest rate. The amount of the interest rate that is set will reduce the borrower's ability to pay its obligations so that this condition can result in high risk.

Table 7. Regression Test

\begin{tabular}{lllll}
\hline \multirow{2}{*}{ Variable Independent } & \multicolumn{2}{c}{ NPL } & \multicolumn{2}{c}{ Z-Score } \\
\cline { 2 - 5 } & Coefficient & Prob. & Coefficient & Prob. \\
\hline C & 1.9322 & 0.0000 & -0.4524 & 0.0812 \\
Competition & $-0.5340^{* * *}$ & 0.0020 & 0.1063 & 0.1883 \\
Income Diversification & 0.6369 & 0.3098 & 0.0012 & 0.9972 \\
Commission & -0.7148 & 0.4119 & -0.0324 & 0.9431 \\
Trading & -0.6273 & 0.1937 & -0.1272 & 0.6558 \\
Non Interest Other & 0.4877 & 0.2420 & 0.1094 & 0.5892 \\
CAR & $-0.2246^{* *}$ & 0.0469 & $1.2604^{* * *}$ & 0.0000 \\
BOPO & $1.1511^{* * *}$ & 0.0000 & $-0.4057^{* * *}$ & 0.0000 \\
\hline
\end{tabular}

\begin{tabular}{lcc}
\hline \multicolumn{1}{c}{ Model Regression } & GLS Cross-section random effects & GLS Cross-section random effect \\
R-squared & 0.2313 & 0.5930 \\
Adjusted R-squared & 0.2170 & 0.5855 \\
F-statistic & 16.1621 & 78.2735 \\
Prob(F-statistic) & 0.0000 & 0.0000 \\
\hline
\end{tabular}

Noted: ${ }^{* * *}$ Significant $1 \%,{ }^{* *}$ Significant $5 \%,{ }^{*}$ Significant $10 \%$

Source: Data Processed, 2020

Insolvency risk ( $Z$ Score) shows that competition has a positive effect but is not significant. These results are the same as the research by Louhichi et al. (2018) as it concerns the conventional banks' sample. His research concludes that low competition characterized by high market power can encourage banks to protect against bank risk-taking behavior in terms of lending, which has an impact on high non-performing loans, which contributes to banking stability from credit sides.

Income diversification has not to effect on risk insolvency (Z Score). The CAR variable has a positive effect. CAR is a measure of bank capital that is used as a buffer against the risk of loss, especially when there is an increase in credit. The larger the CAR, the better the Bank's ability to manage risk, which will have an impact on stability. The BOPO variable has a significant negative effect on the $Z$ Score. This shows that banks with low levels of efficiency tend to have low levels of profit as well. This is because the intermediation function through collecting and distributing a number of funds does not work effectively. The greater the operating expenses incurred, the greater the impact on the Bank's income, so that this will also have a negative impact on the level of stability of a bank. 


\section{DISCUSSION}

This study indicates that the condition of banking competition in Indonesia is in a monopolistic condition. In a monopolistic market, an increase in the cost of production inputs can increase income at a lower rate than the increase in input prices. In other words, in monopolistic competition market conditions, when viewed from the behavior of banks in responding to changes in input prices, every $1 \%$ increase in input prices will increase income output below its proportional value (Mayasari 2012). Furthermore, there are several characteristics in this market, including relatively many producers selling almost similar products and product differentiation offered from each Bank. In other words, a bank sells products slightly different from other banks and is free to enter. Firms can enter (or exit) the market without any restrictions. However, new banks can enter the industry in the long term due to the lack of barriers to entry. In addition, from a price point of view, commercial banks in Indonesia are price makers and not price takers, resulting in high price elasticity of demand. The ability of banks will be equal because demand for products is faced with high price elasticity. This means that in order to increase prices, product differentiation is needed from its competitors, especially in terms of benefits and quality (Harkati et al. 2020). Based on the bank group from the dummy variable, this result does not show differences in competitive behavior in all bank groups. This is because each Bank has a different business segment. In addition, there are business mergers in several banks, especially to small bank groups, thereby increasing competition in monopoly market conditions.

The results of the estimation of competition on stability as measured by two risk proxies indicate that competition significantly affects stability. This research fully supports the paradigm of competition fragility hypothesis (concentration stability) for the condition of Indonesian banking, where banks with large market power will have a stronger bargaining position, making it more likely to obtain high profits, when it succeeds in making a profit, the Bank tends to be careful in carrying out its business activities so that this can reduce the occurrence of credit risk which has an impact on the better stability of the Bank (Wibowo, 2017).

\section{CONCLUSION, LIMITATIONS, AND SUGGESTIONS}

\section{Conclusion}

This study was conducted to prove empirically related to the structure of banking competition and risk in Indonesia during the period 2014 - 2019. Based on the results obtained, it can be concluded that the structure of banking competition in Indonesia is generally in a condition of monopolistic competition. In addition, the results of this study also support the view of the competition fragility hypothesis, where low competition is characterized by a tendency to increase market concentration from 2014-2019 can affect bank behavior in taking smaller risks, thus contributing to stability in terms of profits as shown of a negative NPL value. In addition, banks also need to constantly maintain or increase the level of capital and efficiency in accordance with the standard limits set by the OJK. 


\section{Limitations and Suggestions}

On the dependent variable of the size of the level of bank stability, this study is limited to the scope of bank financial statement data such as the size of NPL and insolvency (Z Score), which calculates the level of profitability, profit volatility, and capital level. Therefore, two indicators better reflect the stability of profits and do not reflect the probability of failure bank. Therefore, in the future, it is recommended for further researchers to add a measure of stability to the default probability measure by considering market aspects. The market aspect in question is the market value of the company's assets, which reflects the prospects and future business value of the company. In addition, this research only focuses on conventional commercial banks. Future researchers can expand on this theme by comparing how competition and stability are between conventional commercial banks and Islamic banks. This is because these two banks have different business and risk profiles model.

\section{REFERENCES}

Abuzayed, B., Al-Fayoumi, N., \& Molyneux, P. (2018). Diversification and bank stability in the GCC. Journal of International Financial Markets, Institutions, and Money, 17-43.

Amidu., S. (2013). Does bank competition and diversification lead to greater stability? Review of Development Finance 3, 152-166.

Apriadi, I., Sembel, R., Santosa, P. W., \& Firdaus, M. (2017). Kompetisi dan Stabilitas Perbankan Indonesia Suatu Pendekatan Analisis Panel Vector Autoregression. Jurnal Manajemen 21(1), 33-54.

Athoillah, M. (2010). Struktur Pasar Industri Perbankan Indonesia: Rosse-Panzar Test. Journal of Indonesian Applied Economics 4(1), 1-10.

Azmi, W., Ali, M., Arshad, S., \& Rzvi, S. A. (2019). Intricacies of competition, stability, and diversification: Evidence from dual banking economies. Economic Modelling 83, 111-126.

Berger, A. a. (1997). "Problem loans and cost efficiency in commercial banks". Journal of Banking and Finance 21(6), 849-870.

Bikker JA, H. K. (2000). Competition, Concentration, and their Reletionship: An Empirical Analysis of the Banking Industry. Journal of Banking and Finance. $26,2191-2214$.

Bikker JA, H. K. (2002). Measure of Competition and Concentration in the Banking Industry : A Review of the Literature. JcoFin 9(2), 53-98.

Bikker., J. S. (2006). Misspecification of the Panzar-Rosse Model : Assesing Competition in the banking industry. Working Paper 114. 
Boyd, J. D. (2005). The theory of bank risk taking and competition revisited. Journal of Finance 60(3), 1329-1343.

Brunnermeier M K, D. G. (2020). Banks' Non-interest Income and Systemic Risk. The Review of Corporate Finance Studies 9(2), 229-255.

Bustaman Y, E. I. (2017). Impact of Interest Margin, Market Power and Diversification Strategy on Banking Stability: Evidence from ASEAN-4. Asian Journal of Business and Accounting 10(1), 1-44.

Cihak, M., \& Hesse, H. (2007). Islamic Bank and Financial Stability: an empirical analysis. Journal Financial Service 38, 95-113.

Clark, E., Radić, N., \& Sharipova, A. (2017). Bank Competition and Stability in the CIS markets. Journal of International Financial Markets, Institutions $\mathcal{E}$ Money 54, 190-203.

Fu, X. L. (2014). Bank competition and financial stability in Asia Pacific. Journal of Banking E Finance, 38(1), 64-77.

Hafidiyah N.M, T. I. (2016). Revenue Diversification, Performance, and Risk Bank: Evidence From Indonesia. Jurnal Dinamika Manajemen 7(2), 139-148.

Hamza, H., \& Kachtouli, S. (2014). Competitive conditions and market power of Islamic and conventional commercial banks. Journal of Islamic Accounting and 5(1), 29-46.

Ibrahim, M., Salim, K., \& Abojeib, M. (2018). Structural Changes, Competition and Bank Stability in Malaysia's Dual Banking System. Economic Systems, https://doi.org/10.1016/j.ecosys.2018.09.001.

Kinanti, S. A. (2017). Pengaruh BOPO, LDR dan ROA terhadap NPL Pada Bank Persero yang Terdaftar di Bursa Efek Indonesia (BEI) Periode 2006-2012. Jurnal Ilmu Manajemen 5(1), 1-9.

Leaven, L., \& Levine, R. (2009). Bank Governance, Regulation and Risk Taking. Journal Financial Economic 93, 259-275.

Lee Chien-Chiang., H. F.-S., \& lee, c.-c. (2014). The relationship between revenue diversification and Bank. Japan and the World Economy 29, 18-35.

Lepetit, L., Nys, E., Rous, P., \& Tarazi, A. (2008). Bank income structure and risk: An empirical analysis of European banks. Journal of Banking and Finance 32, 1452-1467.

Louhichi, L. B. (2018). Market-power,stability and risk taking: ananalysis surrounding the riba-free banking . Review of Accounting and Finance, 14757702.

Mayasari, L. (2012). Analisis Pengaruh Kebijakan Arsitektur Perbankan Indonesia (API) Terhadap Struktur, Perilaku Dan Kinerja Industri Perbankan Indonesia [tesis]. Depok: Universitas Indonesia. 
Moch, N. (2013). Competition in fragmented markets: New evidence from the German. Journal of Banking E Finance 37, 2908-2919.

Molyneux, P., Fu, X., \& Lin, Y. (2014). Bank Competition and Financial Stability in Asia Pacific. Journal of Banking and Finance 38, 64-77.

Mustafa A, T. V. (2017). Estimation of the banking sector competition in the CEE countries: The Panzar-Rosse approach. https://doi.org/10.18045/zbefri.2017.2.459, 459-485.

Navin N, S. P. (2019). Market Structure and Competition in the Indian Microfinance Sector. The Journal for Decision Makers 44 (4), 167-181.

Nguyen, M. S. (2012). Market power, revenue diversification and bank stability:. Journal of International Financial Markets, Institutions \& Money, 897-912.

Noman, M. H. (2017). Does competition improve financial stability of the banking sector in ASEAN countries? An empirical analysis. PLoS ONE 12(5): e0176546.https://doi. org/10.1371/journal.pone.0176546.

OJK, O. (2014-2018, Diunduh Februari 17). ojk.go.id. Retrieved from Otoritas Jasa Keuangan [Internet]: https://www.ojk.go.id/id/kanal/perbankan/datadan-statistics/laporan-keuangan-perbankan/Default.aspx

Revida, R. (2019). Persaingan antar Bank, Diversifikasi Sumber Pendapatan dan Stabilitas Bank pada Bank Umum Syariah dan Konvensional di Indonesia [Tesis]. Surakarta: Universitas Negeri Surakarta.

Sawada, M. (2013). How does the stock market value bank diversification? empirical evidence from japanese Bank. Pacific Basin Finance Journal 25, 40-61.

Sukirno, S. (2011). Mikro Ekonomi Terori Pengantar. Jakarta: Raja Grafindo Persada.

Trinugroho I, R. T. (2018). Competition, diversification, and bank margins: Evidence from Indonesian Islamic rural banks. Borsa Istanbul Review 18(4), 349-358.

Ul-Huq, S. M. (2019). Can BRICS and ASEAN-5 emerging economies benefit from bank diversification? Journal of Financial Regulation and Compliance 27(1), 1358-1988.

Ventouri. (2018). Bank competition and regional integration : Evidence from ASEAN nations. Review of Development Finance https://doi.org/10.1016/j.rdf.2018.08.002.

Wibowo. (2016). Stabilitas Bank, Tingkat Persaingan Antar Bank dan Diversifikasi Sumber Pendapatan: Analisis Per Kelompok Bank di Indonesia. Jurnal Manajemen Teknologi 15 (2), 172-195.

Wibowo, I. E., \& Wibowo, B. (2017). The Effect of Competition Levels and Banking Concentration on Systemic Risk: Indonesia's Case. Indonesian Capital Market Review, 85-100. 